\title{
Effects of dietary Enteromorpha powder on reproduction-related hormones and genes during the late laying period of Zi geese
}

\author{
Wei Qing Ma ${ }^{1}$, Dan Hua Zhao ${ }^{1}$, Huang Zuo Cheng ${ }^{1}$, Si Bo Wang ${ }^{1}$, Ji Yang ${ }^{1}$, Hong Xia Cui ${ }^{1}$, \\ Ming Yuan $\mathrm{Lu}^{1}$, Hong $\mathrm{Zhi} \mathrm{Wu}^{1}$, $\mathrm{Li} \mathrm{Xu}^{1}{ }^{1 *}$, and Guo Jun Liu${ }^{2}$ *
}

\author{
* Corresponding Authors: \\ Li Xu \\ Tel: +86-188-0046-8219, \\ Fax: +86-188-0046-8219 \\ E-mail:xuli_19621991@163.com \\ Guo Jun Liu \\ Tel: +86-187-4606-0877 \\ Fax: +86-187-4606-0877 \\ E-mail: hljlgj0452@163.com
}

${ }^{1}$ College of Animal Science and Technology, Northeast Agricultural University, Harbin 150030, China

${ }^{2}$ Institute of Animal Husbandry of Heilongjiang Academy of Agricultural Sciences, Harbin 150086, China

ORCID

Wei Qing Ma

https://orcid.org/0000-0002-6553-9950 Dan Hua Zhao

https://orcid.org/0000-0002-1683-1744

Huang Zuo Cheng

https://orcid.org/0000-0001-8487-7245

Si Bo Wang

https://orcid.org/0000-0001-7777-3739 Ji Yang

https://orcid.org/0000-0002-6511-7379

Hong Xia Cui

https://orcid.org/0000-0003-3100-6723

Ming Yuan Lu

https://orcid.org/0000-0003-1645-4341 Hong Zhi Wu

https://orcid.org/0000-0001-5722-9357 Li Xu

https://orcid.org/0000-0003-1440-8923

Guo Jun Liu

https://orcid.org/0000-0003-1708-2623

Submitted May 26, 2020; Revised Jul 13, 2020; Accepted Aug 16, 2020
Objective: The aim of this study was to investigate the effects of Enteromorpha powder supplementation on reproduction-related hormones and genes in the late laying period of Zi geese.

Methods: A total of 312 (1-year-old) Zi geese with similar laying rate were randomly divided into 2 groups with 6 replicates each, each with 21 female geese and 5 male geese. The control group was fed with a basal diet and the test group was fed with a diet containing 3\% Enteromorpha powder. The trial period lasted for 7 weeks.

Results: Our results showed that the laying rate was improved in the test group at each week of trial $(\mathrm{p}<0.01)$, and the levels of estradiol in serum and prolactin in ovary were increased compared with the control group $(\mathrm{p}<0.05)$.

Conclusion: Based on above results, Enteromorpha powder supplementation at 3\% could promote reproductive performance during the late laying period of $\mathrm{Zi}$ geese.

Keywords: Enteromorpha Powder; Hormones; Genes; Late Laying Period; Zi Geese

\section{INTRODUCTION}

Enteromorpha is a large green seaweed which reproduces seasonally and can explode in population during summers. Because it is rich in trace elements and biologically active substances, its study has gradually increased. Abudabos et al [1] found that replacing 3\% corn with green seaweed in the diet not only improved the performance of broilers, but also reduced serum total lipid, cholesterol, and uric acid concentrations. Enteromorpha polysaccharide, which is a sort of sulfated polysaccharide extracted from Enteromorpha that has antioxidant, antibacterial, and anticancer effects, is used in the fields of cosmetics, food, and medicine [2]. However, the effects of Enteromorpha or its extracts on reproductive hormones had rarely been reported. It has generally been believed that serum levels of reproductive hormones reflect the body's ability to reproduce. Egg laying is the result of multiple reproductive hormones acting on the ovary, which are in turn regulated by the hypothalamic-pituitary-gonadal (HPG) axis. Gonadotropin-releasing hormone (GnRH) released by the hypothalamus acts on the pituitary to produce gonadotropin. Follicle stimulating hormone (FSH) plays an important role in promoting follicular granulosa cell proliferation. Luteinizing hormone (LH) acts on ovaries to stimulate follicular maturation and ovulation. FSH and LH together regulate follicular synthesis of estradiol (E2) and progesterone (P4) [3-5]. With age, physiological changes reduce both the number and the quality of follicles, resulting in a decrease in egg production and reproductive performance in the late laying period [6-8]. Geese are poultry with low reproductive performance [9], therefore, it is important to study their reproductive hormones and 
genes in the late laying period. This experiment, which was inspired by Abudabos et al [1], substituted some basal feed ingredients with 3\% Enteromorpha powder to improve the reproductive performance of $\mathrm{Zi}$ geese.

\section{MATERIALS AND METHODS}

\section{Animal care}

This experiment was conducted in accordance with the Chinese guidelines for animal welfare and with the animal welfare standards of the College of Animal Science and Technology, Northeast Agricultural University (NEAU-2018-0232).

\section{Experimental design}

A total of 312 (1-year-old) Zi geese with similar laying rate were randomly allocated into two groups, the control group and the test group, each group had 6 replicates, 21 female geese and 5 male geese in each replicate. The control group was fed with basal diet and the test group was fed with basal diet containing 3\% Enteromorpha powder (Table 1). Enteromorpha powder was purchased from Zhongtaihe Biotechnology Co., Ltd., Qingdao, China. Enteromorpha powder contains $6.64 \%$ crude protein, $6.00 \%$ crude fiber, $0.10 \%$ methionine

Table 1. The compositions of the diet and the nutritional level

\begin{tabular}{lcc}
\hline Items & Control group & Test group \\
\hline Ingredient & & \\
Corn (\%) & 39.60 & 39.60 \\
Corn gluten feed (\%) & 21.00 & 18.40 \\
Corn germ meal (\%) & 20.00 & 19.60 \\
Corn oil (\%) & 0.50 & 0.50 \\
Soybean meal (\%) & 10.00 & 10.00 \\
Enteromorpha powder (\%) & 0.00 & 3.00 \\
Limestone (\%) & 3.50 & 3.50 \\
Dicalcium phosphate (\%) & 0.90 & 0.90 \\
Salt (\%) & 0.35 & 0.35 \\
DL-methionine (\%) & 0.15 & 0.15 \\
Lysine (\%) & 0.01 & 0.01 \\
Choline chloride (\%) & 0.08 & 0.08 \\
Zeolite powder (\%) & 3.52 & 3.52 \\
Premix (\%) & 0.39 & 0.39 \\
Total & 100.00 & 100.00 \\
Nutrients & & \\
ME (MJ/kg) & 10.04 & 10.04 \\
CP (\%) & 15.59 & 15.41 \\
Met (\%) & 0.38 & 0.38 \\
Lys (\%) & 0.64 & 0.63 \\
Ca (\%) & 1.64 & 1.68 \\
Total P (\%) & 0.58 & 0.56 \\
\hline
\end{tabular}

$\mathrm{ME}$, metabolizable energy; $\mathrm{CP}$, crude protein

1) Premix provided the following per kg of diet: vitamin A, 15,000 IU; vitamin $D_{3}, 5,300 \mathrm{lU}$; vitamin $\mathrm{E}, 100 \mathrm{mg}$; vitamin $\mathrm{K}, 4 \mathrm{mg}$; vitamin $\mathrm{B}_{1}, 2 \mathrm{mg}$; vitamin $B_{2}, 10$ mg; vitamin $B_{6}, 10$ mg; vitamin $B_{12}, 0.1 \mathrm{mg}$; niacin, $100 \mathrm{mg}$; pantothenic acid, $50 \mathrm{mg}$; folic acid, $2 \mathrm{mg}$; biotin, $0.3 \mathrm{mg} ; \mathrm{Fe}, 120 \mathrm{mg}$; Cu, 20 mg; Zn, 100 mg; Mn, 600 mg, l, 3 mg, Se, 0.5 mg.
(Met), $0.18 \%$ lysine (Lys). All geese were free to eat and drink, and additionally hydrated when the weather was hot. The feed was granular and the straw was used as bedding in the house. According to feeding management, the goose farm adopted natural light. The egg production was recorded daily, and the laying rate was calculated. The feeding trial was carried out at $\mathrm{Zi}$ geese breeding base of the Heilongjiang Academy of Agricultural Sciences. The feeding trial lasted 7 weeks after a 1-week adaptation period.

\section{Sample collection and analysis}

Two female geese from each replication were randomly selected for blood sampling at the end of the fifth week of the experiment. Blood was collected after fasting for $12 \mathrm{~h}$ and centrifuged at 4,000 r/min for $10 \mathrm{~min}$, and the supernatant was collected for analysis. At the end of the experiment, one female goose was selected from reah replication for slaughter, the ovary was taken and stored at $-80^{\circ} \mathrm{C}$, prior to testing. Both serum and ovary GnRH, FSH, LH, prolactin (PRL), E2, and $\mathrm{P} 4$ levels were determined by enzyme-linked immunosorbent assay using kits purchased from Shanghai Youxuan Biotechnology Co., Ltd., Shanghai, China.

\section{Quantification of GnRH1, LHR, and ESR2 genes with} real-time polymerase chain reaction

After the slaughter, the hypothalamus and ovary were carefully removed from female geese, and rapidly preservated at $-80^{\circ} \mathrm{C}$ for determining the relative expression of gonadotropin-releasing hormone 1 (GnRH1) in the hypothalamus, and luteinizing hormone receptor (LHR), and estrogen receptor 2 (ESR2) in the ovary. Primers were designed by Beacon Designer 7 based on goose GnRH1, LHR, and ESR2 gene sequences registered in NCBI, and using the glyceraldehyde3-phosphate dehydrogenase gene as the internal reference gene, as shown in Table 2. Total RNA was extracted from the hypothalamus and ovary using RnaEx reagent. The total volume of the real-time polymerase chain reaction (PCR) reaction system was $10 \mu \mathrm{L}$, and the reaction system was as

Table 2. Fluorescent quantitative primer information

\begin{tabular}{llc}
\hline Genes & \multicolumn{1}{c}{ Primer sequences $\left(\mathbf{5}^{\prime} \mathbf{- 3} \mathbf{3}^{\prime}\right)$} & $\begin{array}{c}\text { Product length } \\
\text { (bp) }\end{array}$ \\
\hline GnRH1 & F: CACAACATCCACATTCTCCTGA & 113 \\
& R: GCGTGCCTGGTGTTCATT & \\
LHR & F: CTGGCTTCTTCACCGTCTT & 173 \\
& R: CACCGCAATCAGGATGGA & \\
ESR2 & F: ACATTGACAGCAGAACACAGT & 187 \\
& R: CAGGAGCAGACCATAACACATT & \\
GAPDH & F:TAGTGAAGGCTGCTGCTGAT & 102 \\
& R:AGGTGGAGGATGGCTGTC & \\
\hline
\end{tabular}

$G n R H 1$, gonadotropin-releasing hormone 1; LHR, luteinizing hormone receptor; ESR2, estrogen receptor 2; GAPDH, glyceraldehyde-3-phosphate dehydrogenase. 
follows: SYBR Green Mix 4.4 $\mu \mathrm{L}$, each of upstream and downstream primers $0.3 \mu \mathrm{L}, \mathrm{cDNA} 5 \mu \mathrm{L}$. The real-time PCR reaction procedure was as follows: $95^{\circ} \mathrm{C}$ for $10 \mathrm{~min}, 1 \mathrm{cycle}, 95^{\circ} \mathrm{C}$ for $10 \mathrm{~s}, 60^{\circ} \mathrm{C}$ for $34 \mathrm{~s}$, and 40 cycles. The $\mathrm{Ct}$ values of the target genes and the internal reference genes were measured, and the relative expression levels of the antioxidant genes were calculated by the $2^{-\Delta \Delta \mathrm{Ct}}$ method.

\section{Statistical analysis}

Data were analyzed using two-tailed Student's T-tests in SPSS 22.0 (SPSS Inc., Chicago, IL, USA). Results were expressed as mean \pm standard deviation. Data significance was considered at $\mathrm{p}<0.05$ and highly significant at $\mathrm{p}<0.01$.

\section{RESULTS}

\section{Production performance}

As shown in Table 3, the control group decreased rapidly from the first week to the third week (the laying rate was less than 5\%), and the test group was close to suspended production at the sixth week. During the whole trial period, the test group had a higher laying rate than the control group $(\mathrm{p}<0.01)$.

\section{Reproductive hormone analysis}

We measured serum reproductive hormones at the fifth week of the trial. As shown in Table 4, the content of E2 in serum from the test group was higher than that of the control group $(\mathrm{p}<0.05)$, however, there was no significant difference between the two groups in any other indicators $(p>0.05)$.

At the end of the trial, we isolated geese ovaries and measured relevant hormone levels, which results are shown in Table 5. The content of PRL in the ovary from the test group was higher than the control group $(\mathrm{p}<0.05)$, and the other indicators were higher than the control group but did not reach a significant level $(\mathrm{p}>0.05)$.

Table 3. Effects of Enteromorpha powder on the laying rate during the late laying period of Zi geese

\begin{tabular}{lcr}
\hline Item & Control group $^{1)}$ & Test group $^{2)}$ \\
\hline $1 w k$ & $13.04^{\mathrm{B}} \pm 1.31$ & $19.50^{\mathrm{A}} \pm 0.45$ \\
$2 w k$ & $6.35^{\mathrm{B}} \pm 0.55$ & $12.81^{\mathrm{A}} \pm 0.69$ \\
$3 w k$ & $4.76^{\mathrm{B}} \pm 0.25$ & $12.02^{\mathrm{A}} \pm 0.60$ \\
$4 w k$ & $3.06^{\mathrm{B}} \pm 0.29$ & $9.52^{\mathrm{A}} \pm 0.82$ \\
$5 w k$ & $2.38^{\mathrm{B}} \pm 0.38$ & $7.94^{\mathrm{A}} \pm 0.45$ \\
$6 w k$ & $0.93^{\mathrm{B}} \pm 0.24$ & $5.16^{\mathrm{A}} \pm 0.18$ \\
$7 w k$ & $1.06^{\mathrm{B}} \pm 0.49$ & $3.84^{\mathrm{A}} \pm 0.32$ \\
$1-7 w k$ & $4.51^{\mathrm{B}} \pm 0.11$ & $10.11^{\mathrm{A}} \pm 0.32$ \\
\hline
\end{tabular}

1) Control group, fed with basal diet.

2) Test group, fed with basal diet contained $3 \%$ Enteromorpha powder.

$A, B$ Means within each row with different letters differ significantly $(p<0.01)$
Table 4. Effects of Enteromorpha powder on reproductive hormone in serum during the late laying period of Zi geese

\begin{tabular}{lcc}
\hline Item & Control group $^{1)}$ & Test group $^{2)}$ \\
\hline $\mathrm{GnRH}(\mathrm{mlU} / \mathrm{mL})$ & $54.73 \pm 3.93$ & $53.82 \pm 3.49$ \\
$\mathrm{PRL}(\mathrm{mlU} / \mathrm{L})$ & $508.43 \pm 23.29$ & $524.03 \pm 26.69$ \\
$\mathrm{LH}(\mathrm{ng} / \mathrm{mL})$ & $190.28 \pm 4.52$ & $191.84 \pm 1.49$ \\
$\mathrm{FSH}(\mathrm{mlU} / \mathrm{mL})$ & $10.17 \pm 0.77$ & $9.90 \pm 0.31$ \\
$\mathrm{E} 2(\mathrm{pg} / \mathrm{mL})$ & $251.09^{\mathrm{b}} \pm 4.60$ & $266.19^{\mathrm{a}} \pm 2.96$ \\
$\mathrm{P} 4(\mathrm{ng} / \mathrm{mL})$ & $5.75 \pm 0.60$ & $5.15 \pm 0.29$ \\
\hline
\end{tabular}

Data are presented as mean \pm standard error of the mean, $n=6$.

$\mathrm{GnRH}$, gonadotropin-releasing hormone; PRL, prolactin; LH, luteinizing hormone; FSH, follicle stimulating hormone; E2, estradiol; P4, progesterone.

${ }^{1)}$ Control group, fed with basal diet.

2) Test group, fed with basal diet contained 3\% Enteromorpha powder.

a,b Means within each row with different letters differ significantly $(p<0.05)$

Table 5. Effects of Enteromorpha powder on reproductive hormone in ovary during the late laying period of Zi geese

\begin{tabular}{lcc}
\hline Item & Control group $^{1)}$ & Test group $^{2)}$ \\
\hline $\mathrm{GnRH}(\mathrm{mlU} / \mathrm{mL})$ & $56.61 \pm 7.15$ & $58.92 \pm 5.37$ \\
$\mathrm{PRL}(\mathrm{mlU} / \mathrm{L})$ & $421.07^{\mathrm{b}} \pm 11.56$ & $499.12^{\mathrm{a}} \pm 17.18$ \\
$\mathrm{LH}(\mathrm{ng} / \mathrm{mL})$ & $165.18 \pm 5.48$ & $182.59 \pm 6.18$ \\
$\mathrm{FSH}(\mathrm{mlU} / \mathrm{mL})$ & $9.67 \pm 1.02$ & $9.95 \pm 0.46$ \\
$\mathrm{E} 2(\mathrm{pg} / \mathrm{mL})$ & $253.89 \pm 15.32$ & $267.75 \pm 13.44$ \\
$\mathrm{P} 4(\mathrm{ng} / \mathrm{mL})$ & $4.82 \pm 0.63$ & $5.23 \pm 0.43$ \\
\hline
\end{tabular}

Data are presented as mean \pm standard error of the mean, $n=6$.

$\mathrm{GnRH}$, gonadotropin-releasing hormone; PRL, prolactin; LH, luteinizing hormone; FSH, follicle stimulating hormone; E2, estradiol; P4, progesterone.

1) Control group, fed with basal diet.

2) Test group, fed with basal diet contained 3\% Enteromorpha powder

$a, b$ Means within each row with different letters differ significantly $(p<0.05)$.

\section{GnRH1, LHR, and ESR2 mRNA expression}

The results of GnRH1, LHR, and ESR2 gene expression were shown in Table 6, and all data in the test group were lower than the control group but did not reach a significant level $(\mathrm{p}>0.05)$.

\section{DISCUSSION}

At the late laying period, the body's ability to regulate ho-

Table 6. Effects of Enteromorpha powder on reproductive hormone gene during the late laying period of Zi geese

\begin{tabular}{lcc}
\hline Item & Control group $^{1)}$ & Test group $^{2)}$ \\
\hline GnRH1 & $1.00 \pm 0.08$ & $0.81 \pm 0.10$ \\
LHR & $1.00 \pm 0.05$ & $0.92 \pm 0.10$ \\
ESR2 & $1.00 \pm 0.05$ & $0.89 \pm 0.07$ \\
\hline
\end{tabular}

Data are presented as mean \pm standard error of the mean, $n=6$. $\mathrm{GnRH1}$, gonadotropin-releasing hormone 1; LHR, luteinizing hormone receptor; ESR2, estrogen receptor 2 .

${ }^{1)}$ Control group, fed with basal diet.

2) Test group, fed with basal diet contained 3\% Enteromorpha powder. 
meostasis of the ovary is reduced $[7,8]$, and environmental changes such as light, temperature, and stress can easily increase ovarian reactive oxygen species levels, reduce DNA stability and mitochondrial function, and release cytochromes. Cytochromes $\mathrm{c}$ in concert with apoptotic factors, leads to apoptosis of follicular granule cells, imbalance of reproductive hormone secretion on the HPG axis, resulting in decreased egg production [10-12]. Our results showed that the egg production rate of both the test group and the control group were negatively correlated with the time since the start of laying, indicating that ovaries had shrank over time and were nearing the discontinuation period by the end of the trial period. Kulshreshtha et al [13] reported that supplementation of 2\% or $4 \%$ red seaweed to 78 -wk-old laying hens produced no significant difference in laying rate between all of the groups in the first to third weeks of the trial, but the laying rate of the test group was significantly improved compared with the control group in the fourth week. Our results were similar in that in our Zi geese supplemented with 3\% Enteromorpha powder, the egg production rate of the test group was significantly higher than the control group at 1 to 7 weeks. This indicated that the Enteromorpha powder could prolong the laying period of $\mathrm{Zi}$ geese and increase egg production, which possibly due to effects of active substances such as brassica polysaccharides and unsaturated fatty acids on regulating reproductive hormone regulation at the HPG axis [14-16].

Generally speaking, GnRH released from the hypothalamus acts on the pituitary to promote the release of $\mathrm{LH}$ and $\mathrm{FSH}$, which in turn acts on ovarian granulosa cells and binds to the corresponding receptors, promoting the growth and development of follicles $[17,18]$. E2 is a steroid hormone secreted by follicular cells and granulosa cells, which can synergize with FSH to promote follicular development and to induce the peak in LH before ovulation [19]. Bluhm et al [20] found that serum LH, PRL, E2, and P4 levels in wild duck laying period were significantly higher than those in the early laying period. The present study found that serum E2 concentration of the test group was significantly higher than the control group, which indicated that E2 was one of the key hormones in laying eggs at the late laying period. E2 can also exert its physiological effects through negative feedback regulation of the HPG axis. Sun et al [21] reported that E2 enhanced L-type calcium channel currents in GnRH neurons through estrogen receptor 2 (ER2) and membrane receptor G-protein coupled receptor 30 and increased excitability of GnRH neurons. Previous studies had shown that E2 has two effects on PRL: one is by directly acting on the pituitary to promote PRL release, and the other is by acting on the hypothalamus to promote the secretion of PRL releasing factor [22]. Zhu et al [23] found that Morinda officinalis polysaccharide could enhance the Kiss 1-GPR54 signaling pathway in the hypothalamus of male rats with varicocele and promoted the synthesis and secretion of GnRH. PRL is a polypeptide hormone secreted by eosinophils in the anterior pituitary and regulated by the upstream hormone GnRH. Many studies had shown that PRL can inhibit the secretion of $\mathrm{LH}$ and FSH, leading to follicular atresia, which is a key factor in inducing nesting behavior in poultry. However, PRL can also promote the development and production of poultry follicles and positively regulate egg production at the early laying period [24]. Yang et al [25] studied the periodic changes of reproductive hormones in Yangzhou geese, which showed that the laying rate was positively correlated with PRL concentration. In this study, ovarian PRL concentration in the test group was significantly increased than that of the control group, although the serum concentration did not reach a significant level, but the test group was also higher than the control group. It indicated that Enteromorpha powder could increase the concentration of PRL in the ovary and maintain $\mathrm{Zi}$ geese staying in the laying state. It had been found that the expression of PRL in the pituitary and plasma was inconsistent. Ishida et al. [26] reported that the concentration of PRL differed between the pituitary and plasma, and the plasma PRL level began to increase 7 days after hatching while the PRL pituitary concentration remained unchanged. Similarly, in this experiment, it was found that E2 and PRL have different levels in serum and ovary, probably because they played a role in different tissues. The increase of E2 and PRL levels in $\mathrm{Zi}$ geese in our test group may have been due to the polyunsaturated fatty acids in Enteromorpha powder promoting the synthesis and secretion of E2 and PRL on the HPG axis.

GnRH1 is mainly secreted by hypothalamic arcuate nucleus GnRH neurons, which can stimulate the release of gonadotropins from the pituitary gland [27]. Previous studies have shown that $G n R H$ gene is related to the reproductive cycle and is expressed in hypothalamus and ovary. Compared with nesting stage, the expression of GnRH gene was significantly higher in the laying stage $[28,29]$. Schirman-Hildesheim et al [30] reported that the expression of GnRH1 mRNA in the ovaries of estrus mice could change with time, which might be related to ovulation. Tran et al. [31] found that unsaturated fatty acids increased GnRH mRNA expression through GPR120 mediated downstream PKC/MAPK and PI3K signaling. LHR is a binding site that mediates the role of LH in the ovary. When the two proteins combine, it stimulates the synthesis and secretion of corpus callosum and promotes gonadal development [32]. ESR2 is an important member of the nuclear transcription factor receptor superfamily and plays an important role in follicular development. In mice with knocked out $E R 2$ gene, the numbers of ovarian follicles and corpus luteum decreased, the number of follicles with atresia and apoptosis increased, and follicular maturation and ovulation were inhibited [33]. Our results showed 
that GnRH1 in the hypothalamus and ovarian LHR and ESR2 gene expression in the test group showed lower levels but did not reach a significant level compared with the control group. It may be that the addition of Enteromorpha powder in diet improves the levels of E2 and PRL in the body, which in turn negatively regulates the HPG axis and decreases the expression of GnRH1, LHR, and ESR2 genes.

In conclusion, dietary supplementation with 3\% Enteromorpha powder significantly increased the egg production, serum E2 concentration, ovarian PRL concentration, and reproductive performance of female $\mathrm{Zi}$ geese.

\section{CONFLICT OF INTEREST}

We certify that there is no conflict of interest with any financial organization regarding the material discussed in the manuscript.

\section{ACKNOWLEDGMENTS}

This work was supported by the Modern Waterfowl Industry Technology System (CARS-42-24) and the Harbin Science and Technology Talent Project (2017RAXYJ201).

\section{REFERENCES}

1. Abudabos AM, Okab AB, Aljumaah RS, Samara EM, Abdoun KA, Al-Haidary AA. Nutritional value of green seaweed (Ulva Lactuca) for broiler chickens. Ital J Anim Sci 2013;12:e28. https://doi.org/10.4081/ijas.2013.e28

2. Wang X, Zhang Z, Yao Z, Zhao M, Qi H. Sulfation, anticoagulant and antioxidant activities of polysaccharide from green algae Enteromorpha linza. Int J Biol Macromol 2013;58: 225-30. https://doi.org/10.1016/j.ijbiomac.2013.04.005

3. Liu T, Li N, Zhu J, et al. Effects of di-(2-ethylhexyl) phthalate on the hypothalamus-pituitary-ovarian axis in adult female rats. Reprod Toxicol 2014;46:141-7. https://doi.org/10.1016/ j.reprotox.2014.03.006

4. McElroy AP, Caldwell DJ, Proudman JA, Hargis BM. Modulation of in vitro DNA synthesis in the chicken ovarian granulosa cell follicular hierarchy by follicle-stimulating hormone and luteinizing hormone. Poult Sci 2004;83:500-6. https:// doi.org/10.1093/ps/83.3.500

5. Palermo R. Differential actions of FSH and LH during folliculogenesis. Reprod Biomed Online 2007;15:326-37. https:// doi.org/10.1016/S1472-6483(10)60347-1

6. Hansen KR, Knowlton NS, Thyer AC, Charleston JS, Soules MR, Klein NA. A new model of reproductive aging: the decline in ovarian non-growing follicle number from birth to menopause. Hum Reprod 2008;23:699-708. https://doi.org/10.1093/ humrep/dem408

7. Burke WH, Attia YA. Molting Single Comb White Leghorns with the use of the Lupron Depot ${ }^{\circledR}$ formulation of leuprolide acetate. Poult Sci 1994;73:1226-32. https://doi.org/10.3382/ ps.0731226

8. Attia YA, Burke WH, Yamani KA. Response of broiler breeder hens to forced molting by hormonal and dietary manipulations. Poult Sci 1994;73:245-58. https://doi.org/10.3382/ps. 0730245

9. El-Hanoun AM, Attia YA, Gad HAM, Abdella MM. Effect of different managerial systems on productive and reproductive traits, blood plasma hormones and serum biochemical constituents of geese. Animal 2012;6:1795-802. https://doi. org/10.1017/S1751731112000808

10.Liu X, Lin X, Mi Y, Li J, Zhang C. Grape seed proanthocyanidin extract prevents ovarian aging by inhibiting oxidative stress in the hens. Oxid Med Cell Longev 2018;2018:9390810. https:// doi.org/10.1155/2018/9390810

11.Sahin E, DePinho RA. Axis of ageing: telomeres, p53 and mitochondria. Nat Rev Mol Cell Biol 2012;13:397-404. https:// doi.org/10.1038/nrm3352

12. Orrenius S, Gogvadze V, Zhivotovsky B. Mitochondrial oxidative stress: implications for cell death. Annu Rev Pharmacol Toxicol 2007;47:143-83. https://doi.org/10.1146/annurev. pharmtox.47.120505.105122

13. Kulshreshtha G, Rathgeber B, MacIsaac J, et al. Feed supplementation with red seaweeds, Chondrus crispus and Sarcodiotheca gaudichaudii, reduce Salmonella enteritidis in laying hens. Front Microbiol 2017;8:567. https://doi.org/10.3389/ fmicb.2017.00567

14.Park NH, Choi JS, Hwang SY, et al. Antimicrobial activities of stearidonic and gamma-linolenic acids from the green seaweed Enteromorpha linza against several oral pathogenic bacteria. Bot Stud 2013;54:39. https://doi.org/10.1186/19993110-54-39

15.Li B, Liu S, Xing R, et al. Degradation of sulfated polysaccharides from Enteromorpha prolifera and their antioxidant activities. Carbohydr Polym 2013;92:1991-6. https://doi.org/ 10.1016/j.carbpol.2012.11.088

16. Moriyama R, Yamazaki T, Kato T, Kato Y. Long-chain unsaturated fatty acids reduce the transcriptional activity of the rat follicle-stimulating hormone $\beta$-subunit gene. J Reprod Dev 2016;62:195-9. https://doi.org/10.1262/jrd.2015-138

17. Kermath BA, Gore AC. Neuroendocrine control of the transition to reproductive senescence: lessons learned from the female rodent model. Neuroendocrinology 2012;96:1-12. https://doi.org/10.1159/000335994

18. Schally AV, Arimura A, Kastin AJ, et al. Gonadotropin-releasing hormone: one polypeptide regulates secretion of luteinizing and follicle-stimulating hormones. Science 1971;173:10368. https://doi.org/10.1126/science.173.4001.1036

19. Soede NM, Langendijk P, Kemp B. Reproductive cycles in pigs. Anim Reprod Sci 2011;124:251-8. https://doi.org/10.1016/ j.anireprosci.2011.02.025 
20. Bluhm CK, Phillips RE, Burke WH. Serum levels of luteinizing hormone (LH), prolactin, estradiol, and progesterone in laying and nonlaying canvasback ducks (Aythya valisineria). Gen Comp Endocrinol 1983;52:1-16. https://doi.org/10.1016/ 0016-6480(83)90152-1

21.Sun J, Chu Z, Moenter SM. Diurnal in vivo and rapid in vitro effects of estradiol on voltage-gated calcium channels in gonadotropin-releasing hormone neurons. J Neurosci 2010; 30:3912-23. https://doi.org/10.1523/JNEUROSCI.6256-09. 2010

22. Mauro LJ, Elde RP, Youngren OM, Phillips RE, El Halawani ME. Alterations in hypothalamic vasoactive intestinal peptidelike immunoreactivity are associated with reproduction and prolactin release in the female turkey. Endocrinology 1989; 125:1795-804. https://doi.org/10.1210/endo-125-4-1795

23.Zhu Z, Huang F, Wang F, Zhang Y, Zhao X, Wang W. Morinda officinalis polysaccharides stimulate hypothalamic $\mathrm{GnRH}$ secretion in varicocele progression. Evid Based Complement Alternat Med 2017;2017:9057959. https://doi.org/10.1155/ 2017/9057959

24. Sharp PJ, Blache D. A neuroendocrine model for prolactin as the key mediator of seasonal breeding in birds under long- and short-day photoperiods. Can J Physiol Pharmacol 2003;81:350-8. https://doi.org/10.1139/y03-025

25. Yang HM, Wang Y, Wang ZY, Wang XX. Seasonal and photoperiodic regulation of reproductive hormones and related genes in Yangzhou geese. Poult Sci 2017;96:486-90. https:// doi.org/10.3382/ps/pew340

26. Ishida H, Shimada K, Sato K, et al. Developmental expression of the prolactin gene in the chicken. Gen Comp Endocrinol 1991;83:463-7. https://doi.org/10.1016/0016-6480(91)901 53-W

27. Moore JP, Wray S. Luteinizing hormone-releasing hormone (LHRH) biosynthesis and secretion in embryonic LHRH neurons. Endocrinology 2000;141:4486-95. https://doi.org/ 10.1210/endo.141.12.7814

28. Goubau S, Bond CT, Adelman JP, et al. Partial characterization of the gonadotropin-releasing hormone $(\mathrm{GnRH})$ gene transcript in the rat ovary. Endocrinology 1992;130:3098-100. https://doi.org/10.1210/en.130.5.3098

29. Kang SW, Thayananuphat A, Rozenboim I, Millam JR, Proudman JA, El Halawani ME. Expression of hypothalamic GnRH-I mRNA in the female turkey at different reproductive states and following photostimulation. Gen Comp Endocrinol 2006;146:91-9. https://doi.org/10.1016/j.ygcen.2005.10.017

30.Schirman-Hildesheim TD, Bar T, Ben-Aroya N, Koch Y. Differential gonadotropin-releasing hormone (GnRH) and $\mathrm{GnRH}$ receptor messenger ribonucleic acid expression patterns in different tissues of the female rat across the estrous cycle. Endocrinology 2005;146:3401-8. https://doi.org/10. 1210/en.2005-0240

31.Tran DQ, Ramos EH, Belsham DD. Induction of Gnrh mRNA expression by the $\omega-3$ polyunsaturated fatty acid docosahexaenoic acid and the saturated fatty acid palmitate in a GnRH-synthesizing neuronal cell model, mHypoA-GnRH/ GFP. Mol Cell Endocrinol 2016;426:125-35. https://doi.org/ 10.1016/j.mce.2016.02.019

32. Patel H, Bhartiya D, Parte S, Gunjal P, Yedurkar S, Bhatt M. Follicle stimulating hormone modulates ovarian stem cells through alternately spliced receptor variant FSH-R3. J Ovarian Res 2013;6:52. https://doi.org/10.1186/1757-2215-6-52

33. Fitzpatrick JL, Mize AL, Wade CB, Harris JA, Shapiro RA, Dorsa DM. Estrogen-mediated neuroprotection against $\beta$-amyloid toxicity requires expression of estrogen receptor $\alpha$ or $\beta$ and activation of the MAPK pathway. J Neurochem 2002;82:674-82. https://doi.org/10.1046/j.1471-4159.2002. 01000.x 